\section{Bra om type 2-diabetes}

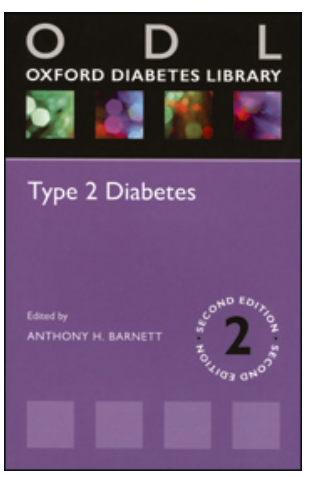

Anthony H. Barnett, red.

Type 2 diabetes

2. utg. 162 s, tab, ill. Oxford: Oxford University

Press, 2012. Pris GBP 20

ISBN 978-0-19-959617-1

Dette er en liten håndbok om type 2-diabetes. Den ligger godt $i$ hånden og får plass $i$ frakkelommen.

Det er velkomment med en ny liten håndbok, da type 2-diabetes dessverre også øker mye i vårt land. Vi står på mange måter bare og ser på at epidemien utvikler seg. Vi vet hva som må gjøres for å begrense epidemien - stanse vektøkningen i befolkningen - men gjør det ikke. I mellomtiden må vi behandle pasientene best mulig. Denne boken kan bidra til det. Bidragsyterne diskuterer mange kliniske studier og balanserer fint synspunktene.

Men hvem er boken laget for? I forordet står det at den er laget for det tverrfaglige teamet og er «ekstremt praktisk». Nei, det er den dessverre ikke. Den refererer til enkeltundersøkelser, mens en begrenset bok som denne bør være et «destillat» av nåtidens kunnskap og ikke sette enkeltundersøkelser opp mot hverandre. Den mangler praktiske flytskjemaer for hvordan man skal behandle pasienten. Det er klart at online informasjon har mye for seg $i$ en slik situasjon.

Men som vanlig kan vi lære av britisk medisin. Britene har klart å gjennomføre fotografisk screening for diabetisk retinopati. Dette er både kostnadseffektivt og sparer mange øyelegeårsverk.

Det er en del perler i teksten, f.eks. i kapitlet Challenges to good diabetes care: «The care of diabetes requires a multi-disiplinary approach with the person with the condition caring for themselves on a day to day basis in partnership with a number of different health care professionals.» Dette er den største utfordringen: å hjelpe pasienten til å ta ansvar for egen behandling i en travel hverdag.

Jeg mener slett ikke at dette er en dårlig bok, men den henvender seg mer til slike som meg som har stor interesse for diabetes, enn det tverrfaglige teamet den ifølge forordet er skrevet for.

\section{Kristian F. Hanssen}

Endokrinologisk avdeling

Oslo universitetssykehus

\section{Ubalansert om testosteronmangel}

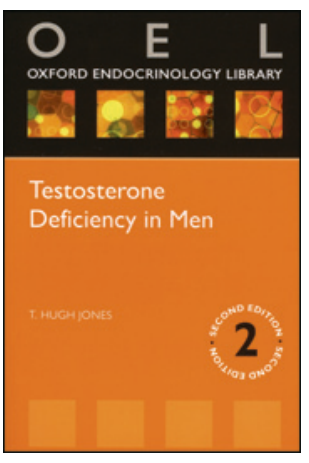

T. Hugh Jones

Testosterone deficiency in men

2. utg. 163 s, tab, ill. Oxford: Oxford University Press, 2012. Pris GBP 20

ISBN 978-0-19-965167-2

Denne oppdaterte boken om mannlig hypogonadisme retter seg etter min mening primært mot allmennleger. Boken er en grei sammenfatning av utredning og behandling av klassisk hypogonadisme, for eksempel Klinefelters syndrom, Kallmanns syndrom og hypogonadisme ved hypofysesvikt.

I en stor del av boken er dog søkelyset rettet mot den aldrende mannen. Det er godt akseptert at testosteronnivået synker med økende alder, selv om variasjonen mellom ulike menn er stor. Mannlig hypogonadisme er preget av et lavt serumtestosteronnivå i kombinasjon med et mangfold av symptomer og tegn, som redusert libido og vitalitet, redusert muskelmasse, økt fettmasse og depresjon. Liknende symptomer i kombinasjon med subnormalt testosteronnivå kan også ses hos eldre menn, og flere forsøk er blitt gjort for å identifisere symptomer og tilsvarende testosteronnivå for å definere sent innsettende hypogonadisme som en egen tilstand. Men symptomer på testosteronmangel hos eldre menn er uspesifikke og vanskelige å skille fra symptomer på andre tilstander og sykdommer som er vanlige hos eldre menn.

Her savner jeg en nyansert og kritisk holdning til den forskningen og de retningslinjene som forfatteren refererer til. Anbefalingene fra for eksempel Endocrine Society (USA) er alle basert på svært lav eller lav vitenskapelig evidens. Den forskningen som refereres til, er primært epidemiologiske studier og små behandlingsstudier. Ti år etter Women's Health Initiative, hvor man undersøkte effekten av østrogenbehandling hos mer enn 16000 postmenopausale kvinner, finnes fortsatt ingen store, langvarige, placebokontrollerte studier med testosteron gitt til hypogonadale menn (og slett ingen studier der testosteron har vært gitt til eldre menn uten sikker hypogonadisme). Til tross for denne usikkerheten har salget av testosteron økt enormt de siste årene.

Det er ingen tvil om det finnes behov for å øke kunnskapen om mannlig hypogonadisme, men i boken til T. Hugh Jones savner jeg et balansert bilde.

\section{Johan Svartberg}

Endokrinologisk seksjon

Medisinsk klinikk

Universitetssykehuset Nord-Norge 